\title{
Some aspects of the biochemical basis of metabolic adaptation
}

\author{
Kandula Pampapathi Rao \\ Department of Zoology, Sri Venkateswara University, Tirupati, A.P., India
}

KURZFASSUNG: Einige Aspekte der biochemischen Basis metabolischer Adaptation. Die Reihenfolge biochemischer Vorgänge während der Kälte-Akklimatisierung konnte in einer Vielzahl von Organismen verfolgt werden. Die Änderungen betreffen eine Verminderung freier Aminosäuren, ein Ansteigen von RNA, gebundenen Aminosäuren und Gewebeproteinen. Die Intensität der Proteinsynthese ist höher bei kaltadaptierten Individuen, und eine Reihe von Enzymen zeigt vermehrte Aktivität. Gleichzeitig steigt der Gehalt an Ascorbinsäure und Cytochrom $c$ an. Es erfolgt eine Verschiebung des Kohlehydratstoff wechsels, wobei der HMPCyclus bei Kälteakklimatisierung dominiert, was vielleicht mithilft, den Vorrat an Pentosen für Nukleinsäure zu vergrößern und auch eine Zunahme an Ascorbinsäure verursacht. Bedeutsame Veränderungen erfolgen auch in Substanzen, welche mit dem Lipidstoffwechsel in Beziehung stehen; es kommt zu einem auffallenden Ansteigen der Entsättigung von Lipiden, was eine bevorzugte Mobilisierung gesättigter Tri-Glyzeride anzeigt. Die Lipase-Aktivität erhöht sich, desgleichen die Aktivität mehrerer anderer Enzyme. Dieser verstärkte Lipidabbau bedingt eine Vermehrung im Gehalt an Phospholipiden (was vielleicht mithilf, Mitochondrienfraktionen aufzubauen), Ketonkörpern und Cholesterin. Neben diesen Veränderungen im Zellstoffwechsel erfolgen wichtige Veränderungen im Gehalt an bedeutsamen Ionen der Körperflüssigkeiten. So sind bei Kälteakklimatisation Calcium, Kalium und Natrium vermehrt im Blut oder in den Körperflüssigkeiten vorhanden, während Magnesium, Sulfat und Chlorid abnehmen. Derartige Veränderungen führen zu erhöhtem Muskelstoffwechsel, ermöglichen eine größere Aktivität des Organismus und kompensieren damit die erniedrigte Temperatur. Alle angeführten Anderungen stehen wahrscheinlich unter hormoneller oder neurohumoraler Kontrolle. Eine Sterolfraktion, die im ZNS und in der Körperflüssigkeit kaltadaptierter Regenwürmer, Skorpione und Fische enthalten ist, hatte in vitro einen direkten Effekt auf die Geweberespiration normaler Individuen und regte den Stoffwechsel sehr stark an. Extrakte, welche von warm-akklimatisierten Individuen erhalten wurden, hatten eine entgegengesetzte Wirkung. Diese Effekte sind nicht artspezifisch. Offenbar werden Stoff wechselregulationen bei den meisten vielzelligen Kaltblütern, welche Temperaturänderungen kompensieren, von neurohumoralen (oder hormonalen) Agentien ausgelöst und reguliert.

\section{INTRODUCTION}

The mechanisms underlying the process of compensation to temperature in metabolism and activity of poikilotherms have been studied in detail, but only recently have such investigations been extended to cellular processes. The pioneering studies of PRECHT and his collaborators have directed attention to compensatory changes 
occurring in the activity of some of the metabolic enzymes such as the dehydrogenases. Investigations in our laboratory in the past few years, using the earthworm Lampito mauritii, the fish Etroplus maculatus and the scorpion Heterometrus swammerdami as experimental animals, have shown an interesting sequence of biochemical changes. I shall briefly recapitulate these results here in order to provide a background for new results to be presented and discussions of our present knowledge.

\section{PERTINENT RESULTS OBTAINED IN OUR LABORATORY}

In cold-acclimated individuals an increase in the bound amino acids at the cellular level paralleling a decrease in free amino acids in the body fluids was noticed, and along with this there was an increase in the total protein within cells and tissues (Rao 1962, Raghupathiramireddy \& Rao 1963, Saroja \& Rao 1965). Both interferometric analysis of dry matter in cells (RAO 1963c) and microkjeldahl analysis of protein nitrogen in tissues (SAROJA \& RAO 1965) showed an increase in tissue protein. A parallel increase in RNA content was noticeable, and this was most marked in metabolically active tissues (RAO 1963c, SAROJA \& RAO 1965). Such changes in protein and RNA levels have since been confirmed in cold-acclimated fish also by DAs (1965).

These changes in amino acids and increase in RNA and protein on cold acclimation indicate an increase in the rate of protein synthesis in cold-acclimated individuals. Such increased protein synthesis in cold-acclimated frogs has earlier been indicated by the work of JANKOWSKY (1960), who showed an increased rate of incorporation of labelled glycine in cold-acclimated individuals. More recently DAS (1965) working in Prosser's laboratory has also confirmed this in goldfish using labelled L-leucine. He found that 12 hours after injection of ${ }^{14} \mathrm{C}$-leucine the protein from the gills of $5^{0} \mathrm{C}$ adapted fish showed 50 to $60 \%$ more ${ }^{14} \mathrm{C}$ incorporation than that of $25^{\circ} \mathrm{C}$ adapted fish. Muscle protein exhibited a higher degree of variability, although the $5^{\circ} \mathrm{C}$ fish tended to show a higher radio-active incorporation than the $25^{\circ} \mathrm{C}$ fish. Such an increased protein synthesis may help to increase enzyme protein. This can be seen in a number of dehydrogenases and other enzymes which increased on cold acclination (Prosser 1962). Likewise cytochrome $c$ also increases on cold acclimation (SAROJA \& RAO 1965).

Besides these changes in enzymatic levels which apparently are related to increased protein synthesis, there is also a shift in the carbohydrate metabolism, the HMP pathway predominating in cold-acclimated individuals (EKBERG 1958, HoCHACHKA \& HAYEs 1962). This presumably helps in the supply of pentoses to the nucleic acids and thus might be related to increased protein synthesis. Likewise there is an increase in the ascorbic acid level and the tissue glycogen level in cold acclimation (SAROJA \& RAO 1965). Associated with the decrease in free amino acids and increased level of metabolic enzymes, there is also a decrease in oxalo-acetate content, perhaps indicating an increase in the rate of the TCA cycle. The above results, most of which have been published earlier, are briefly summarized in Tables 1 and 2. 
Table 1

Changes related to carbohydrate and protein metabolism occurring during acclimation to low temperature in the earthworm Lampito matritii

\begin{tabular}{|lcc|}
\hline Criteria & $\begin{array}{c}\text { Cold-acclimated } \\
\left(20^{\circ} \mathrm{C}\right)\end{array}$ & $\begin{array}{c}\text { Warm-acclimated } \\
\left(35^{\circ} \mathrm{C}\right)\end{array}$ \\
\hline Glycogen & +++ & + \\
HMP activity & + & \pm \\
Ascorbic acid & + & + \\
RNA & + & + \\
Free amino acids & + & + \\
Protein N & - & + \\
\hline
\end{tabular}

Table 2

Changes in metabolic (respiratory) enzymes and adenine nucleotide during acclimation to low temperature in the scorpion Heterometrus swammerdami

\begin{tabular}{|lll|}
\hline Criteria & $\begin{array}{c}\text { Cold-acclimated } \\
\left(20^{\circ} \mathrm{C}\right)\end{array}$ & $\begin{array}{c}\text { Warm-acclimated } \\
\left(35^{\circ} \mathrm{C}\right)\end{array}$ \\
\hline Succinic dehydrogenase & $0.8987 \pm 0.2434$ & $0.1675 \pm 0.054$ \\
Malic dehydrogenase & $0.8437 \pm 0.1728$ & $0.1355 \pm 0.0415$ \\
Lactic dehydrogenase & $0.9287 \pm 0.1593$ & $0.1544 \pm 0.0342$ \\
Pyruvic dehydrogenase & $0.6935 \pm 0.1286$ & $0.1865 \pm 0.0464$ \\
Cytochrome C. & 0.4429 & $0.0702^{1}$ \\
Adenosine diphosphate (ADP) & $1.3737 \mu \mathrm{moles} / \mathrm{gm}$ & $0.8082 \mu \mathrm{moles} / \mathrm{gm}$ \\
Adenosine triphosphate (ATP) & $3.124 \mu \mathrm{M} / \mathrm{gm}$ & $2.040 \mu \mathrm{M} / \mathrm{gm}$ \\
ATP/ADP ratio & 2.27 & 2.52 \\
1 Expressed as percent autoxidizable cytochrome c; ${ }^{2} \mu \mathrm{gm}$ of formazan per mg/hr.
\end{tabular}

Besides the above mentioned cellular metabolic changes, a series of changes occur in the ionic composition of the body fluids which apparently are due to systemic organismic controlling factors. These have been discussed in detail clsewhere (RAo $1962,1963 \mathrm{a}, \mathrm{d})$, but the main results may briefly be mentioned here. Acclimation to low temperature results in an increase of calcium, potassium and sodium in the blood and body fluids while magnesium, sulphate and chloride show a significant decrease. The significance of these shifts in ionic levels in blood and body fluids, as shown in detail earlier (RAO 1963a, d), lies in the fact that they result in increased muscle metabolism and therefore permit increased activity of the organism, which thus compensates for lowered temperature.

Another very important finding was that a factor or factors contained in the body fluids or nerve tissue extracts of the earthworms or scorpions or in the blood serum of fish, has a direct effect on the respiration of tissues of these organisms in vitro (Rao 1962, Rao \& Saroja 1963, Vijayalakshmi 1964). Extracts obtained from coldacclimated individuals greatly enhance the oxygen consumption of tissues of normalor warm-acclimated individuals, when added to the perfusion fluids in vitro even in very small quantities. On the other hand extracts from warm-acclimated individuals lower the tissue respiration (Rao \& Saroja 1963, Saroja \& Rao 1965). These effects, 
which we reported first in 1962, have since been confirmed in investigations by PRECHT (1964) and JANKowsky (1964). Using the fishes Idus idus and Cyprinus carpio, PreCHT (1964) has shown that this serum factor not only affects the tissue oxygen consumption but also alters even the heat resistance of the oxygen consumption of the tissues in vitro. Further, these factors are apparently not species specific but act interspecifically.

However, we do not yet have any knowledge of the precise nature of these active principles. Quite recently we have further analyzed this problem by extracting the sterol fraction from the central nervous system of the cold-acclimated earthworms. Such a sterol fraction from cold-acclimated earthworms has a very marked effect on the respiration of tissues from normal worms, enhancing the oxygen consumption very greatly ( $73 \%$ over normal), even when administered in very small quantities (NAYEEMUNNISA 1965).

\section{FURTHER RESEARCH}

The results mentioned above raise a number of questions, the answers to which we have sought by further analyses of cellular metabolic processes in the earthworm. An important question arises in regard to the mitochondrial enzymes; if there were to be increased protein synthesis and an increase in several of the mitochondrial enzymes, then there should be an increase in the structural components of the mitochondria. The phospholipids constitute one such important component essential to the structural integrity of the mitochondria. Another interesting inference from the above presented results relates to the turnover of lipids. It was mentioned above that the glycogen content increases during cold acclimation and that activity of the HMP shunt and protein synthesis increase as well. This would imply that one of the immediate sources of energy in cold acclimation is lipid. One may expect therefore a greater utilization of the preferentially mobilizable lipids (viz., saturated triglycerides), at least in the initial stages of cold acclimation. Further, the need to utilize more of steroids for hormone-like substances would demand greater availability of the precursor, cholesterol.

All these considerations point to the need for a closer examination of the lipid metabolism in cold acclimation. We have therefore examined some aspects of this part of metabolism, and I will present our results briefly before I pass on to a discussion of the sequence of events that are postulated.

\section{LIPID METABOLISM}

The main results are summarized in Table 3 . It is seen that there is a conspicuous increase in the unsaturation of lipids as determined by the iodine number. This may be interpreted to mean that saturated triglycerides are mobilized preferentially and lipolyzed, leaving behind the unsaturated lipids, which help in the preservation of the liquid crystalline state of the cellular membranes. With decrease in acclimation temperature, an increase in unsaturation presents a means for maintaining the system near 
Table 3

Changes related to lipid metabolism occurring during acclimation to low temperature in the earthworm Lampito mauritii

\begin{tabular}{|lcc|}
\hline Criteria & $\begin{array}{c}\text { Cold-acclimated } \\
\left(20^{\circ} \mathrm{C}\right)\end{array}$ & $\begin{array}{c}\text { Warm-acclimated } \\
\left(35^{\circ} \mathrm{C}\right)\end{array}$ \\
\hline $\begin{array}{l}\text { Unsaturation of lipids (Iodine number) } \\
\text { (whole worm) }\end{array}$ & 42.66 & 25.47 \\
Activity of lipase (whole worm) & 286.25 & 104.38 \\
Phospholipids (whole worm) & 5.901 & $5.059 \mathrm{percent}$ dry wt. \\
Volatile Fatty Acids: & & \\
(a) Formic (Body fluid) & 23.81 & $32.32 \mathrm{mg} / 100 \mathrm{ml}$ \\
(b) Acetic (Body fluid) & 37.44 & $33.89 \mathrm{mg} / 100 \mathrm{ml}$ \\
Ketone bodies: & & \\
(a) Acetone (Body fluid) & 15.28 & $8.71 \mathrm{mg} / 100 \mathrm{ml}$ \\
(b) $\beta$-Hydroxy butyric (Body fluid) & 56.23 & $48.42 \mathrm{mg} / \mathrm{ml}$ \\
Cholesterol (Nervous System) & 31.47 & $16.953 \mathrm{mg} / \mathrm{gm} \mathrm{wt}$. \\
\hline
\end{tabular}

the critical point of a phase transition. It has earlier been mentioned that the level of ascorbic acid increases on cold acclimation. Ascorbic acid is a strong antoxidant and therefore could be responsible for the prevention of the oxidation of unsaturated fatty acids, especially at the double bond level in the molecule (Fruton \& Simmonds 1960) and thus may also help in the preservation of the liquid crystalline state of cellular membranes.

The activity of the lipases increases very greatly, indicating increased lipolysis, which also may be augmented by the increase in ascorbic acid. The increase in the lipase itself may be a result of increased protein synthesis which results in increased enzyme protein. Lipolysis of the triglycerides results in glycerol and fatty acids. The former is a precursor in the formation of phospholipid. We notice an increase in phospholipids on cold acclimation. This increase in phospholipid may have important consequences. It is well known that phospholipids are essential for the structural integrity of the mitochondria and therefore an increase in phospholipid content may lead to stimulation of the mitochondrial enzyme systems and also to an increase in the mitochondrial fraction itself, which is desirable in cold acclimation. Indeed, Dr. JANKOWSKY has informed me that he has evidence which indicates such an increase in the mitochondrial fraction on cold acclimation.

The other result of increased lipolysis can be that it leads to increased $\beta$-oxidation, which would result in a greater production of acetyl CoA. Such an increased availability of acetyl CoA might (as one possibility) result in greater production of ketone bodies as well as increased production of cholesterol and choline. Our estimations show that there is a great increase in cholesterol content in the nerve cord of coldacclimated earthworm (Table 3 ). This increased cholesterol will be available for the production of steroid hormones or equivalent substances.

The interrelations likely to exist between the various changes in cellular reactions during cold acclimation noticed above have been discussed in detail by RAO (1963d), RAO \& SARoja (1963) and SARoja \& RAO (1965). It has been indicated that hormones 
or hormone-like substances released during cold acclimation in to the "milieu interieur" can trigger and control a series of changes leading to the biochemical alterations summarized above. They may directly influence RNA synthesis, thus leading to the increased protein synthesis noticed. Alternate metabolic pathways may be activated, such as, for example, the HMP shunt, which in its turn might help increase RNA synthesis and also lead to increased production of ascorbic acid. Enzyme activities would be enhanced, not only through such direct action of activators, but also through increased enzyme protein synthesis and the presence of increased levels of ascorbic acid. Thirdly, these hormone-like substances may increase the mobilization of saturated triglycerides, which would lead to increased lipid metabolism. This results (1) in greater availability of phospholipids, which in turn permit greater activity of mitochondrial enzymes, and (2) in increased $\beta$-oxidation leading to increased production of acetyl $\mathrm{CoA}$ and cholesterol. These active principles could also bring about systemic changes, the altered ionic ratios bringing about enhanced muscle metabolism and activity. And finally the hormone-like factors which are released into the body fluids can affect tissue respiration directly as shown by our studies. The net result of all these actions of such active principles would be to enhance metabolism and activity of the organism compensating for the effects of lowered temperature.

\section{CONTROL MECHANISMS}

Having considered the biochemical sequence of events occuring during cold acclimation, the question arises as to what control mechanisms operate in organisms of different levels of organization. Three possible modes of operation are conceivable.

(1) Changes in temperature may directly affect the cellular systems and cause enzyme induction and alterations in metabolic rate. This is known to happen in many lower organisms without central regulatory mechanisms. Examples of such cases are bacteria, yeast and similar other forms. It is conceivable that even coelenterates and related metazoans may have similar mechanisms involving direct effects of temperature.

(2) Changes in temperature may affect the nervous system. The influence may be of the nature of nervous regulation, muscular activity or metabolic activity of specific organs such as the liver. Perhaps in vertebrates there may be an interaction between nervous and endocrine systems. Direct effects of the nervous system on tissue metabolism appear to be of limited consequence even in higher forms, elaborate humoral control dominating.

(3) Most important of all, changes in temperature may activate one or more humoral systems, causing the release of hormones or hormone-like substances which in turn can trigger the processes mentioned above, i. e., protein synthesis, enzyme activitics, ionic changes, metabolic pathways, tissue respiration and so on. I consider that in most metazoa with body fluid or blood, this humoral control of biochemical mechanisms of metabolic compensation is the most common and predominant one. Of course the possibility of such humoral agents being released from different kinds of 
tissues must also be taken into consideration as being distinct from the humoral agents known to be normally released from neuroendocrine systems.

If metabolic compensation to temperature is thus based on fundamental biochemical processes of cellular metabolism, we should expect such biochemical mechanisms to operate similarly during metabolic rate changes caused by effects other than temperature changes. The biochemical changes occuring in insect growth parallel the sequences just described. Indeed it has recently been shown by VROMAN, KAPLANIS \&

Table 4

Changes occurring in certain metabolically important substances during aestivation in the snail Pila globosa. (After Raghupathiramireddy 1965)

\begin{tabular}{|lcc|}
\hline Criteria & Active snails & Aestivating snails \\
\hline Catalase activity & $57.34 \pm 4.93$ & $54.43 \pm 5.45^{1}$ \\
RNA & $4.20 \pm 1.16 \mathrm{mg} / \mathrm{gm}$ & $4.03 \pm 0.26 \mathrm{mg} / \mathrm{gm}$ \\
Alcohol dehydrogenase & $625 \pm 94.74^{2}$ & $329 \pm 58.64^{2}$ \\
Succinic & $486 \pm 103.6^{2}$ & $225 \pm 54.55^{2}$ \\
Glutamic & $363 \pm 95.76^{2}$ & $139 \pm 39.13^{2}$ \\
Cytochrome oxidase & $384.25 \pm 57.58$ & $167.00 \pm 36.26^{3}$ \\
Cytochrome C. & $26.97 \pm 2.86 \mu \mathrm{g} / \mathrm{gm}$ & $10.33 \pm 1.59 \mu \mathrm{g} / \mathrm{gm}$ \\
Adenine + Adenosine & $14.04 \pm 1.702 \mathrm{mg} / 100 \mathrm{gm}$ & $7.95 \pm 1.86 \mathrm{mg} / 100 \mathrm{gm}$ \\
Adenosine monophosphate (AMP) & $8.660 \pm 2.135 \mathrm{mg} / 100 \mathrm{gm}$ & $7.705 \pm 1.535 \mathrm{mg} / 100 \mathrm{gm}$ \\
Adenosine diphosphate (ADP) & $25.85 \pm 4.234 \mathrm{mg} / 100 \mathrm{gm}$ & $8.483 \pm 1.856 \mathrm{mg} / 100 \mathrm{gm}$ \\
Adenosine triphosphate (ATP) & $52.40 \pm 8.25 \mathrm{mg} / 100 \mathrm{gm}$ & $93.31 \pm 11.54 \mathrm{mg} / 100 \mathrm{gm}$ \\
ATP/ADP ratio & 2.03 & 11.0 \\
ATP ase activity & $2.49 \pm 0.38$ & $0.48 \pm 0.204$ \\
Magnesium (in blood) & $(-)$ & $(+)$ \\
1 Enzyme activity expressed as amount of HgO & in gms destroyed by gram wet tissue in \\
one hour. - 2 Enzyme activity expressed as $\mu \mathrm{g}$ of formazan formed by gram wet weight \\
of tissue. - - Enzyme activity expressed as $\mu \mathrm{ng}$ netetrazolium chloride reduced per gram \\
weight of tissue in one hour. - ${ }^{4}$ Enzyme activity expressed as mg of inorganic phosphate \\
released from ATP by gram tissue in one hour. \\
\hline
\end{tabular}

Robins (1965) that lipid biosynthesis and turnover in the female cockroach are controlled by the corpora allata. Allatectomy noticeably slowed down the turnover of both the triglycerides and the phospholipid, indicating that the corpora allata produce a factor which selectively mobilizes the saturated triglycerides.

Even more remarkably similar are the biochemical changes that occur in slowing down metabolism during aestivation of the snail Pila globosa, which was investigated in our laboraty by RAgHupathiramireddy (1965). It can be seen from Table 4 that the changes expected in warm acclimation (requiring a slowing down in metabolic rate) occur here in aestivation. Enzyme activities are reduced and the ATP/ADP ratio increases. Even the ionic change, e. $g$. in regard to magnesium, is similar to warm acclimation, even though there is no temperature change. In $P$. globosa too the switching down of metabolic rate is triggered by a steroid fraction obtainable from the central nervous system (MEENAKshr 1956); the same has been shown by us to happen during warm acclimation in earthworms, scorpions and fish.

It follows thus that the basic mechanisms controlling metabolic rate may be similar under diverse conditions as long as raising or lowering of rates is required. 


\section{SUMMARY}

1. In cold-acclimated animals the free amino acids in body fluids decrease, while the bound amino acids and the total protein within cells and tissues increase.

2. A parallel increase in RNA content is noticed, along with an increase in the rate of protein synthesis. A number of dehydrogenases and other enzymes as well as cytochrome $\mathrm{c}$ increase during cold acclimation.

3. There is a shift in the carbohydrate metabolism, resulting in the predominance of the HMP pathway. Ascorbic acid level and tissue glycogen increase during cold acclimation.

4. Cold acclimation furthermore results in an increase of calcium, potassium, and sodium in blood and body fluids while magnesium, sulphate and chloride show a significant decrease. These changes may result in increased muscle metabolism permitting increased activity of the organism.

5. The unsaturation of lipids (iodine number) increases, indicating preferential mobilization of saturated triglycerides in cold acclimation. Lipase activity increases greatly. Phospholipids, which help in regard to the structural integrity of mitochondria, also show an increase. Ketone bodies and cholesterol increase significantly.

6. Factors contained in body fluids or nerve tissue extracts of acclimated earthworms, scorpions or fish have direct effect on the respiration of tissues of normal organisms in vitro (RAO 1962, RAO \& SAROJA 1963). The sterol fraction of such extracts appears to contain the active principle.

7. It is indicated that hormone or hormone-like substances released into the "milieu interieur", during acclimation, trigger and control a series of changes leading to the biochemical alterations summarized above.

8. Similar changes, but in the opposite direction, occur in slowing down metabolism during the aestivation of the snail Pila globosa. The switching down of metabolic rate, in this case as well, is triggered by a sterol fraction obtainable from the central nervous system.

9. Considering the biochemical mechanisms in acclimation to be similar in different organisms, three possible modes of triggering and control are suggested, namely, direct effects of temperature, effects of the nervous system and, most important of all, regulation through the release of hormones or hormone-like substances.

\section{LITERATURE CITED}

DAs, A. B., 1965. Protein synthesis in temperature acclimation of goldfish, Carassius auratus. Am. Zoologist 5, 230.

Fruton, J. S. \& Simmonds, S., 1960. General biochemistry [2nd ed. Wiley, New York, 1958 (Asia Publ. House, Bombay)], 1077 pp.

JANKOWsKY, H. D., 1960. Uber die hormonale Beeinflussung der Temperaturadaptation beim Grasfrosch (Rana temporaria). Z. vergl. Physiol. 43, 392-410.

- 1964. Der Einfluß des Blutes auf den Sauerstoff verbrauch des isolierten Muskelgewebes von Schleien (Tinca tinca L.). Zool. Anz. 172, 233-239.

NAYEEMUNNISA, 1965. Unpublished observations. 
Precht, H., 1964. Über die Bedeutung des Blutes für die Temperaturadaptation von Fischen. Zool. Jb. (Allg. Zool. Physiol. Tiere) 71, 313-327.

Prosser, C. L., 1962. Acclimation of poikilothermic vertebrates to low temperatures. In: Comparative physiology of temperature regulation. Ed. by J. P. Hannon \& E. Viereck. Arctic Aeromed. Lab., Ft. Wainwright, Alaska, Pt 3, 1-44.

Raghupathiramireddy, S., 1965. Doctoral diss. submitted to the Sri Venkateswara Univ., Tirupati, A. P., India.

- \& RAO, K. P., 1963. Physiology of low temperature acclimation in tropical poikilotherms. 3. Quantitative changes in the bound and free amino acids in the earthworm, Lampito mauritii. Proc. Indian Acad. Sci. 58, 1-10.

Rao, K. Pampapathr, 1962. Physiology of acclimation to low temperature in poikilotherms. Science 137, 682-683.

- 1963a. Physiology of low temperature acclimation in tropical poikilotherms. 1. Ionic changes in the blood of the freshwater mussel L. marginalis and the earthworm Lampito mauritii. Proc. Indian Acad. Sci. 57, 290-296.

- 1963b. Physiology of low temperature acclimation in tropical poikilotherms. 2. Interferometric analysis of blood cells in the freshwater mussel, L. marginalis and the earthworm Lampito mauritii. Proc. Indian Acad. Sci. 57, 297-299.

- 1963c. Physiology of low temperature acclimation in tropical poikilotherms. 4. Quantitative changes in the nucleic acid content of the tissues of the freshwater mussel, L. marginalis. Proc. Indian Acad. Sci. 58, 11-13.

- 1963d. Some biodhemical mechanisms of low temperature acclimation in tropical poikilotherms. In: The cell and environmental temperature. Ed. by A. S. Troshin. USSR Acad. Sci., Moscow; Pergamon pr., Oxford, U. K., 98-112.

- \& Saroja, K., 1963. Physiology of low temperature acclimation in tropical poikilotherms. 5. Changes in the activity of neurosecretory cells in the earthworm Lampito mauritii and evidence for a humoral agent influencing metabolism. Proc. Indian Acad. Sci. 58, 14-18.

Saroja, K. \& Rao, K. Pampapath, 1965. Some aspects of the mechanism of thermal acclimation in the earthworm Lampito manritii. $Z$. vergl. Physiol. 50, 35-54.

ViJayalakshmi, C., 1964. Studies on the metabolism of scorpions with special reference to thermal acclimation. Doctoral diss. submitted to the Sri Venkateswara Univ., Tirupati, A.P., India.

Vroman, H. E., Kaplanis, J. N. \& Robbins, W. E., 1965. Effect of allatectomy on lipid biosynthesis and turnover in the female American cockroach, Periplaneta americana (L.) J. Insect Physiol. 11,897-904.

\section{Discussion following the paper by RAO}

KinNe: I am pleased to hear about the advances that have been achieved in regard to the investigation of the biochemical basis of non-genetic metabolic adaptations. You distinguish control mechanisms at the cellular, nervous system and humoral system levels and come to the conclusion that release of hormones or hormone-like substances are most important. On the basis of knowledge available thus far, this latter conclusion seems somewhat surprising. Would you care to comment on that?

RAO: As $I$ have pointed out earlier, it is suggested that the nature of the control mechanisms depends on the level of organization. I believe, on the basis of evidence thus far available, that in highly organized metazoans with a circulating body fluid, hormones or hormone-like substances play an important role. Such a conclusion is not so surprising in view of the fast accumulating evidence of the important role of hormones in metabolic regulation in a variety of organisms, including the worms, molluscs, crustaceans, insects and vertebrates. This of course does not rule out an interaction between nervous and hormonal control.

Roberts: One of my student, Dr. A. J. PEnICNak, has made a pilot study of the ultrastructure of liver cells from cold and warm acclimated sunfish, L. gibbosus, $\left(10^{\circ}\right.$ and $\left.18^{\circ} \mathrm{C}\right)$ for 
purposes of identifying differences which can be related to thermal history. The only obvious difference found was a considerably greater accumulation of glycogen granules in the cells from cold acclimated fish.

RAO: It is an interesting observation. Such an increase in glycogen bodies would be expected from the results we have reported from our laboratory.

ROBERTS: A second comment I would like to make refers to current studies on temperature adaptations by species of Hydra (Park strains, $H$. littoralis, H. psendoligactis). Curiously, population growth both in numbers and in hydra mass is remakably independent of temperature. Although acclimation of budding frequency in single individuals is apparent (half-time about 4 days), no clear evidence for acclimation has been found in the output frequency of rhythmic potentials.

KINNE (to RoBerts): As I understand it, you have tested the effects of two constant temperature levels, namely $10^{\circ}$ and $20^{\circ} \mathrm{C}$. Don't you think that testing more temperature levels - say $5^{0}, 10^{\circ}, 15^{\circ}, 20^{\circ}, 25^{\circ} \mathrm{C}$ - or employing fluctuating temperature patterns could possibly have revealed differences in population growth or frequency of rhythmic potential output? The identical values obtained at $10^{\circ}$ and $20^{\circ} \mathrm{C}$ respectively may have been the result of selecting by chance two temperature levels which happen to produce similar responses.

Roberts (to KrNNE): As far as the temperature is concerned, we do find some evidence although our study is not yet completed - that growth may actually be slightly faster at $15^{\circ} \mathrm{C}$ than it is at $10^{\prime \prime}$ or $20^{\circ} \mathrm{C}$.

PRECHT: Wir haben bisher im wesentlichen Betriebsstoffwechselprozesse gemessen, bei denen man früher eine Leistungsadaptation oft übersehen hat, weil man die Temperatur zu rasch änderte, ohne daß den Tieren Zeit gelassen wurde, sich anzupassen. Bei der Untersuchung von Entwicklungsprozessen hat man die Tiere (vor allem Insekten) bei konstanten Temperaturen gehalten, also voll adaptierte Tiere gemessen und übersehen, daß plötzliche Temperaturänderungen andere Effekte haben können. Ein wieder anderes Problem stellen die jahreszeitlichen Anpassungen dar, die auch Sie untersuchten. Hier haben neben der Temperatur auch andere Faktoren (wie die Tageslänge) eine große Bedeutung, die zu entsprechenden Effekten führen können, wie Thre Versuche zeigten. Bei den Tieren unseres Klimas ist es oft so, daß der Stoffwechsel im Winter erhöht ist, wenn unter den gleichen Bedingungen gemessen wird wie im Sommer, es sei denn, die Tiere weisen besondere Ruhestadien auf, die zumeist durch einen reduzierten Stoffwechsel gekennzeichnet sind.

RAO: I have no remarks to offer.

Precht: Ich wollte lediglich darauf hinweisen, daß die jahreszeitlichen Verschiebungen nicht ausschließlich auf die Temperatur zurückgehen. Aber nun zu den Aalversuchen, auf die mich Herr RAO ansprach. Beim Aal können das Vorder- und Hinterende an unterschiedliche Temperaturen angepaßt werden. Der Sauerstoffverbrauch des Muskelgewebes der kaltadaptierten Teile ist relativ hoch, derjenige der warmadaptierten Enden relativ niedrig. Wir glaubten darin einen Beweis für eine direkte Einwirkung der Adaptationstemperatur auf das Gewebe zu sehen, doch wandte Dr. Prosser mit Recht ein, daß ebenfalls Teile des Rückenmarks gleichzeitig an verschiedene Temperaturen angepaßt wurden. Die Zahl der von den Rückenmarksteilen an die Muskulatur gesandten spikes hing auch von der Adaptationstemperatur ab, so daß diese das Gewebe eventuell nur indirekt beeinflußte (vgl. Naturwiss. 52, 168, 1965). Versuche mit Aalen, deren Rückenmark durch Ausbohren zerstört wird, sollen dies Problem klären. Der Sauerstoffverbrauch des intakten Aales hängt nur von dem Adaptationszustand des Kopfendes $a b$, nicht von dem des Hinterendes und somit auch nicht vom Sauerstoff verbrauch, den dessen Muskelgewebe bei Messungen im Warburgapparat zeigt (Schultze, Z. wiss. Zool. 172, 104, 1965).

HEss: Ich glaube, in diesem Kreise ist es notwendig, darauf hinzuweisen, daß eine ganze Reihe von enzymatischen Reaktionen in der Zelle temperaturabhängig sind: Bei den exothermen Reaktionen verschieben sich die Verhältnisse der Reaktionspartner in Abhängigkeit von der Temperatur über einen großen Bereich. Dies trift bei der Glykolyse z. B. für die Phosphofructo- 
kinasereaktion oder die Aldolasereaktion zu. Die Reaktionspartner derartiger Reaktionen könnten als Temperaturdiskriminatoren funktionieren. Dr. Chance hat vor einigen Jahren bei der Untersuchung der stationären Zustände von FAD und FADH in Mitochondrien ebenfalls eine starke Temperaturabhängigkeit ihres Produktverhältnisses gefunden. Man kann sich vorstellen, daß die stationären Konzentrationen von Reaktionspartnern derartiger Reaktionen unter dem Einfluß der Außentemperatur verschoben werden und dann durch Induktion und Repression Enzymmuster verändern. - Es ist nicht möglich, aus Veränderung der Metabolitkonzentration allein, z. B. von Oxalacetat etwas über den Fluß eines Systems auszusagen. Ein Absinken des Spiegels von Oxalacetat an sich besagt gar nichts, wenn nicht zur gleichen Zeit der Nettofluß durch das System bekannt ist. Ich wäre dankbar, wenn Herr Dr. Rao uns noch mehr über seinen Temperaturfaktor sagen und weiter noch über die Methode der Oxalacetatbestimmung Auskunft geben kann.

RAo: The oxaloacetate was estimated by the method of ToNhazY, WhIte \& UmbreIt (1950) as described in Colowick \& Kaplan (1955): Methods in Enzymology. This involves decarboxylation to pyruvate. The point mentioned by Dr. Hess is worth considering, but the changes occurring during acclimation should be considered in their totality and as related to each other. We have only suggested some of the possibilities.

MnLLER: I would like to ask Dr. Rao three questions in regard to the steroid fraction obtained from tissues of cold-acclimated animals which increases the oxygen uptake of tissues in vitro: (1) Is this extract present in all tissues of cold-acclimated animals or in the brain only? (2) Does it stimulate oxygen uptake of all tissues? (3) Is it absent - or present in small amounts only - in non-cold-acclimated individuals?

RAo: We have not studied the several tissues separately. The active principle is present in the nervous tissue and also in the body fluid. We have measured its effect on muscle tissue in earthworms and fish, and on the hepatopancreas tissue in scorpions. Oxygen consumption of intact worms, into which the extract is injected, also shows a marked increase. It is therefore possible that it stimulates oxygen consumption of most of the tissues. It is probably absent in the noncold-acclimated individuals since we never noticed any stimulation of tissue respiration using extracts from such individuals.

KINNE: In regard to non-genetic adaptation to different constant temperature levels, I would like to point out that organisms may not only be able to acclimate to different constant intensities. Even though specific investigations have not been carried out to my knowledge, it seems safe to assume that organisms are able to acclimate to different patterns of intensity changes of environmental factors. Since such changes represent more natural conditions than constant intensities, there is urgent need for investigating responses to periodic or unperiodic undulations of temperature as well as of other environmental factors.

SCHLIEPER: Herr KInNe hat darauf hingewiesen, daß es vermutlich nicht nur eine Akklimatisation an konstante Temperaturen, sondern auch an Temperaturwechsel geben kann. Ich möchte das bestätigen; wir haben Flußkrebse an regelmäßigen Temperaturwechsel, nachts kalt, tags warm, adaptiert. Fin Teil der Versuchstiere adaptierte dann so, daß die temperaturabhängigen Sauerstoffverbrauchsunterschiede zunehmend geringer wurden. Am Schluß der langfristigen Adaptation zeigten einige Versuchstiere sogar ein konstantes mittleres Stoffwechselniveau ungeachtet der rhythmisch wechselnden Wassertemperatur.

Kinne: Vielen Dank für diese interessante Mitteilung. Vermutlich spielt neben dem Rhythmus oder dem Muster der Temperaturänderungen insbesondere auch die Ges chwindig k e it der Anderung eine wichtige Rolle. Für das betroffene Individuum dürtten derartige Anpassungen wohl primär unter stoffwechsel-ökonomischen Aspekten zu sehen sein, und zwar im Sinne einer Wiederherstellung maximaler biologisch-energetischer Nutzeffekte ("efficiencies") nach umweltbedingten Störungen.

Prechr: Wenn wir die Fermentaktivität messen, dann begnügen wir uns zumeist mit e i n e $\mathrm{r}$ konstanten Versuchstemperatur. Nun möchte ich Herrn Kollegen Hess fragen: wie könnte man Fermentaktivitäten unter sich verändernden Temperaturbedingungen messen? 
Hess: Bei der Untersuchung des Temperatureinflusses auf enzymatische Systeme ist es notwendig, zwischen zwei verschiedenen Wirkungen zu unterscheiden: Einmal ein Temperatureinfluß auf die Enzymaktivität, der innerhalb von msec bis sec zu beobachten ist und zweitens ein Temperatureinfluß auf die Enzymsynthese, der erst nach Minuten oder Stunden meßbar ist und auf Induktion und Repression beruht.

ZErSBERGER: It seems difficult to compare acclimation processes in such different organisms as homoeotherms, insects and protozoans. The mechanisms of temperature adaptation may be in these animals quite different.

HEss: Es ist anzunehmen, daß die Reaktion von metabolischen Systemen qualitativ in allen Spezies die gleiche ist, da die fundamentalen Stoffwechselreaktionen überall die gleichen sind. Man kann höchstens erwarten, daß durch die funktionelle Spezifität gewisse quantitative Unterschiede zu beobachten sind. Ich möchte bei dieser Gelegenheit die Biologen fragen, ob sie wissen, welches biochemische System in einem Organismus primär die Temperatur wahrnimmt.

LOCKER: Es läßt sich denken, daß in einem System die Reaktion mit der höchsten (scheinbaren) Aktivierungsenergie oder (im Sinne der Theorie der absoluten Reaktionsgeschwindigkeit) Aktivierungsenthalpie dafür bestimmend ist. Sie reagiert am stärksten gegenüber der Temperatur; von ihr aus erfolgt eine Anderung des ganzen Systems. Eine entsprechende Hypothese hat C. Sorokrn (Biochim. Biophys. Acta 38, 197, 1960) über die bei tiefer oder hoher Temperatur führende, aber jeweils nicht gleiche Reaktion geäußert. 